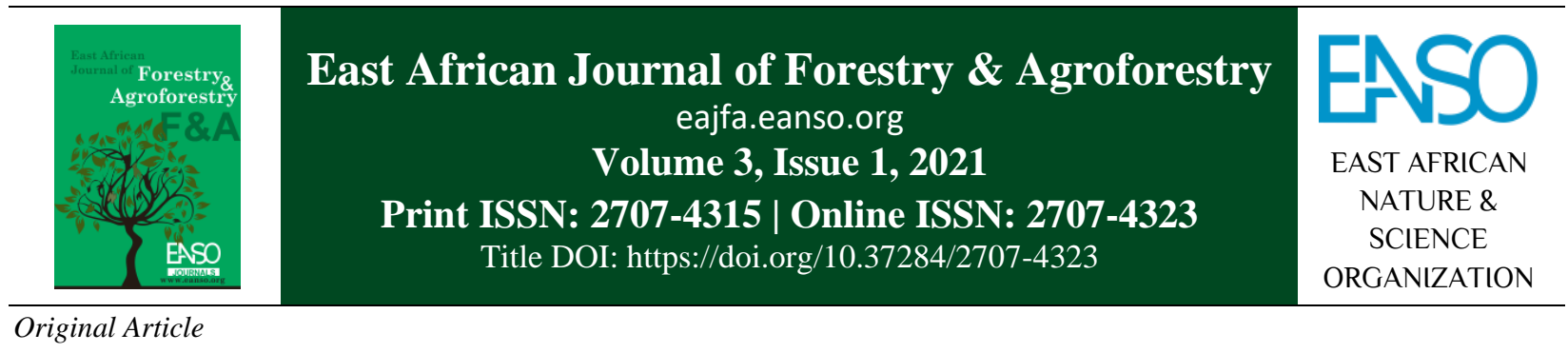

\title{
Conservation Activities of Women in Nyangores Forest Station, Mau Conservancy, Kenya
}

\author{
Jared Bitange ${ }^{1 *}$, Dr. Peter Sirmah, $P h D^{1}$, \& Dr. Thomas Matonyei, PhD ${ }^{1}$ \\ ${ }^{1}$ Department of Agroforestry, Environmental Studies and Integrated Natural Resource Management, University of Kabianga, P. \\ O. Box 2030-20200, Kericho, Kenya. \\ * ORCID: https://orcid.org/0000-0002-6619-5870; Author for Correspondence email: psirmah@kabianga.ac.ke.
}

Article DOI: https://doi.org/10.37284/eajfa.3.1.288

\section{Date Published: ABSTRACT}

08 March 2021 Community-based forest management has increasingly gained popularity in many parts of developing countries. Although the roles of

Keywords: women in forest conservation, management and sustainable utilisation, as well as livelihood improvement, are of paramount importance, it is

Women, still scarce and unaddressed in new forest management approaches.

Forest Conservation, Structured questionnaires were administered to 248 Nyangores Nyangores Forest, community forest association members to capture the forest Mau Conservancy, conservation activities of women, determine their role in community Kenya. forest management and evaluate their socio-economic benefits. Results indicate tree seedling propagation $(87.1 \%)$, monitoring and evaluation $(\mathrm{M} \& \mathrm{E})(85.1 \%)$, and protection of regenerates $(84.7 \%)$ as the major forest conservation activities. Minor roles included timber harvesting (22.9\%), enrichment planting, silvicultural operations (12.9\%), and firefighting (8.5\%). Accrued socio-economic benefits as a result of women's role in forest management and conservation were freshwater $(95.6 \%)$ and firewood $(94.8 \%)$. These results suggest the incorporation of both genders as a pre-requisite for the success of community forest conservation programs in Mau Conservancy, Kenya.

\section{APA CITATION}

Bitange, J., Sirmah, P., Matonyei, T. (2021). Conservation Activities of Women in Nyangores Forest Station, Mau Conservancy, Kenya East African Journal of Forestry and Agroforestry, 3(1), 29-39. https://doi.org/10.37284/eajfa.3.1.288

\section{CHICAGO CITATION}

Bitange, Jared., Peter Sirmah, Thomas Matonyei. 2021. "Conservation Activities of Women in Nyangores Forest Station, Mau Conservancy, Kenya”. East African Journal of Forestry and Agroforestry 3 (1), 29-39. https://doi.org/10.37284/eajfa.3.1. 288.

29 | This work is licensed under a Creative Commons Attribution 4.0 International License. 


\section{HARVARD CITATION}

Bitange, J., Sirmah, P., Matonyei, T. (2021), "Conservation Activities of Women in Nyangores Forest Station, Mau Conservancy, Kenya”, East African Journal of Forestry and Agroforestry, 3(1), pp. 29-39. doi: 10.37284/eajfa.3.1. 288.

\section{IEEE CITATION}

J. Bitange, P. Sirmah, T. Matonyei, "Conservation Activities of Women in Nyangores Forest Station, Mau Conservancy, Kenya”, EAJFA, vol. 3, no. 1, pp. 29-39, Mar. 2021.

\section{MLA CITATION}

Bitange, Jared., Peter Sirmah, Thomas Matonyei. "Conservation Activities of Women in Nyangores Forest Station, Mau Conservancy, Kenya”. East African Journal of Forestry and Agroforestry, Vol. 3, no. 1, Mar. 2021, pp. 29-39, doi:10.37284/eajfa.3.1. 288.

\section{INTRODUCTION}

Forests are valuable natural resource components of any community, region or country in sub-Saharan Africa and play a fundamental role in the socioeconomic well-being of those communities (Usman et al., 2016). Indeed, forests contribute to the ecological conservation of soil, water, and biodiversity, which in turn provide various ecosystem goods and services such as food, fuelwood, medicinal ingredients, and timber to the surrounding local communities (Musyoki et al., 2013; Geller et al., 2006). It has been estimated that approximately 1.2 to 1.5 billion people are forestdependent (Chao, 2012; Weiss et al., 2012; Agrawal et al., 2013). World's commission on forests and sustainable development postulates that 350 million of the world's poorest people almost completely depend on forests for their subsistence and livelihood.

Despite dependence on forests, human activities have led to its degradation and consequent gradual disappearance locally and regionally. This is largely driven by increasing population coupled with widespread poverty levels among communities living adjacent to forest resources, hence exerting pressure on the already dwindling forest resources (Musyoki et al., 2013). Over the past decades, there's been an intense global campaign on increasing the forest cover of each nation, and several international instruments such as legislations have been enacted to guide this endeavour. Against this background, concerted efforts have been put locally in Kenya through legislation on the sustainable management of forest resources. This involves allowing co-management of natural resources such as by provision of the Kenya Forest Conservation and Management Act (2016) which recognises the involvement of forest adjacent communities in sustainable management. This particular Act has led to the development of Participatory forest management (PFM), which involves a multi-stakeholder approach where the private sector, institutions and communities are involved in management and sharing of benefits (Yemshaw, 2007).

In Nepal and India, community forestry programs were initially conceived to reverse the degradation of national forests, which could not be managed and protected effectively by state forestry services (Springate-Baginski \& Blaikie, 2003). In Africa alone, about twenty-one nations have adopted Participatory Forest Management (PFM), a decentralised form of forest resources management (Mutune et al., 2015). This management style is widely favoured as opposed to the centralised form because it enables the participation of local communities in forest management through environmental-sensitive utilisation (Mutune et al., 2015).

Women are known primary consumers of forest products such as firewood (Leone, 2013; Shackleton et al., 2011) and have highly specialised knowledge of trees and forests in terms of biological diversity, sustainable management, use for various purposes, and conservation practices (FAO, 2016). However, their role in value chains tends to be poorly supported by policy-makers and extension services. The perpetual lack of genderdisaggregated data hampers the development of policy interventions to address such issues (FAO, 2016; FAO, 2011). Policies and practices empowering women in the forest sector yield significant benefits to food security and nutrition and the sustainable management of forests. Facilitating women's participation in forest user groups, improving their access to modern sources of 30 This work is licensed under a Creative Commons Attribution 4.0 International License. 
energy, and enhancing their access to processing techniques and markets have been found to make a major difference in the livelihoods of forestdependent people and their societies.

A sizeable body of literature provides evidence that women are generally under-represented in forest user groups, such as village forest committees and Community Forest Associations (CFA) (Agarwal, 2001; Coleman \& Mwangi, 2013). Several authors have suggested that the inclusion of women in forest management is necessary for efficiency and improved livelihoods (Williams, 1992; Agarwal, 2001). According to Sen (2000), involving women in environmental projects require special efforts to extend their participation beyond the traditional roles accorded them. Women are currently involved in many forest conservation activities in Kenya, but their contribution to those particular organisations is not adequately studied. This research, therefore, seeks to examine the role of women in forest conservation activities in the Nyangores community forest Kenya and the resulting socio-economic benefits. The knowledge generated would provide vital insights that inform policies of gender inclusiveness in community forest associations and bring a better understanding of the implications of equity in the operations of community forest conservation groups.

\section{MATERIALS AND METHODS}

\section{Study Area}

Nyangores forest is located in the South Western end of Trans Mara forest block, Kenya with an area of about 13,142 hectares (Ha). It borders Bomet County to the South and Southwest, Olenguruone forest to the North and Nairotia forest to the east (Figure 1). It lies within an altitude of $2000-3000$ meters above sea level. The community around the forest is registered as Nyangores Community Forest Association.

Figure 1: Location of Nyangores Community Forest

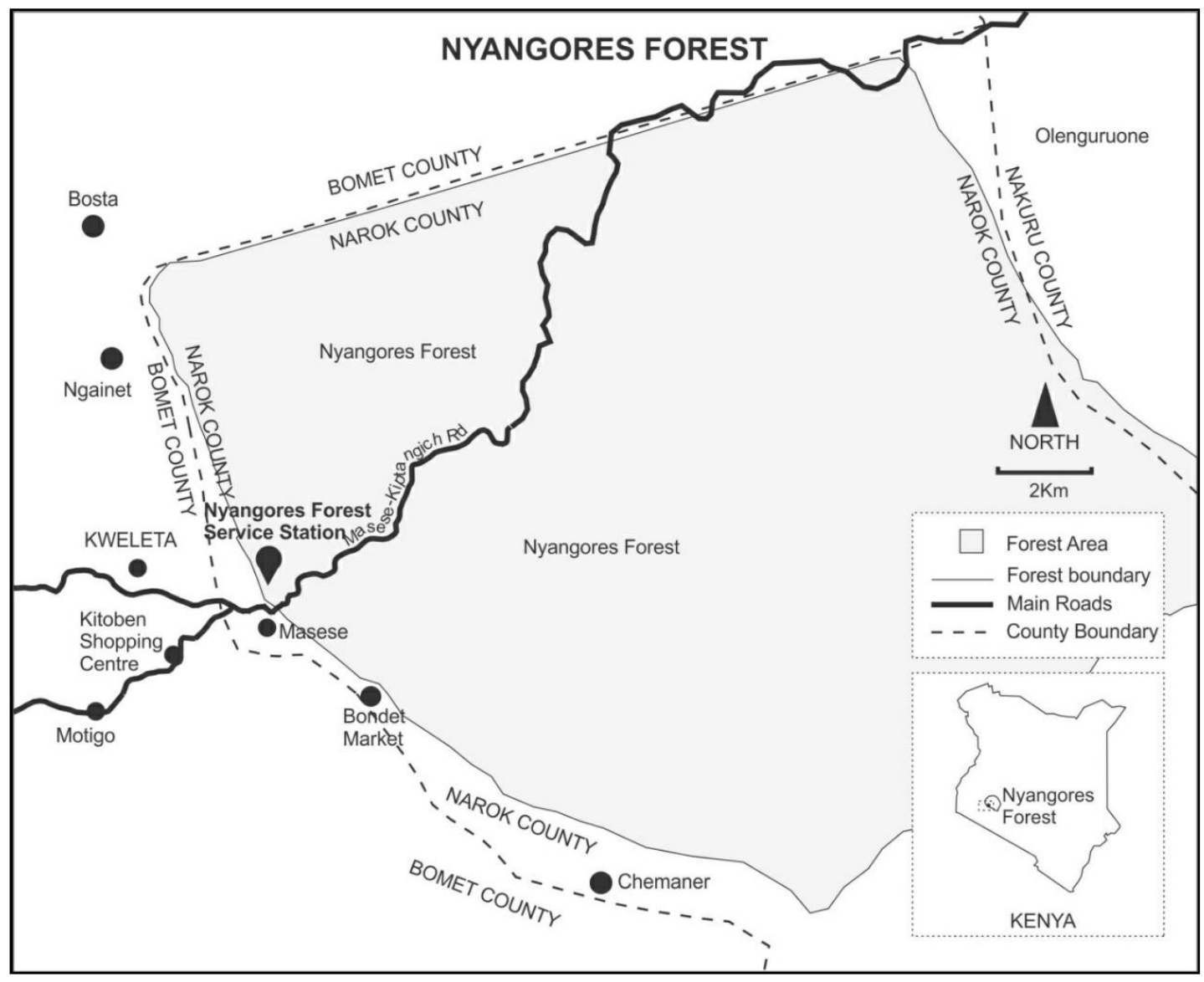

31 This work is licensed under a Creative Commons Attribution 4.0 International License. 
Nyangores community forest receives an average annual rainfall of about $2000 \mathrm{~mm}$ and temperature range $12^{\circ} \mathrm{C}-16^{\circ} \mathrm{C}$. The forest is drained by a pattern of parallel rivers, namely; Kipsonoi,
Nyangores, Ainapngetunyet, Chepkositon and Timongigo with sources in Mau forest reserve and discharging their waters into river Nyangores. The vegetation type in the forest station is mainly montane (4230 Ha) (Table 1).

Table 1: Vegetation Types of Nyangores Forest Station

\begin{tabular}{l|l}
\hline Forest type & Area $($ Ha) \\
\hline Montane forest & 4230 \\
Bamboo /trees & 70 \\
Bamboo & 4230 \\
Shrubs & 3430 \\
Grassland & 100 \\
Tree plantation & 70 \\
Nyayo tea zone & 820 \\
\hline
\end{tabular}

Source: (Kenya Forest Management Plan, 2017)

\section{Research Design and Sampling}

This study was carried out between April 2019 and July 2019 following a descriptive research design. The study targeted all the 827 members of Nyangores Community Forest Association (CFA) who were engaged in conservation and joint management of Nyangores forest resources. Out of this target population, sample sizes of $30 \%$ (248 respondents) were randomly selected according to Mugenda and Mugenda (2014).

\section{Data Collection}

A structured questionnaire was administered to the 248 sampled members of the Nyangores Community Forest Association (CFA). The structured questionnaires, consisting of closedended questions, covered the community demographic aspects, socio-economic profiles of the respondents, information on socio-economic benefits of the forest, forest conservation activities in Nyangores forest and the roles of women in Community Forest management. Additional information was also received by interviewing key informants representing the Kenya Forest Service (KFS) and other relevant government agencies and non-governmental organisations (NGOs) involved in the conservation of Nyangores forest. All the data collection tools were pre-tested and verified for effectiveness with few randomly selected members before use.

\section{RESULTS AND DISCUSSION}

\section{Demographic Profile of Nyangores Community Forest Association members}

Table 2 presents demographic profiles and socioeconomic trends of Nyangores community forest association members.

Table 2: Demographic characteristics Nyangores Community Forest Association

\begin{tabular}{lll}
\hline Demographic profile of respondents & & Proportion of the total $(\%)$ \\
\hline Gender & Male & 69 \\
Age (year) & Female & 31 \\
& $18-25$ & 9.3 \\
& $26-33$ & 26.6 \\
& $34-41$ & 37.5 \\
Marital Status & $42-49$ & 16.9 \\
& Over 50 & 9.7 \\
\hline
\end{tabular}

32 This work is licensed under a Creative Commons Attribution 4.0 International License. 
East African Journal of Forestry and Agroforestry, Volume 3, Issue 1, 2021

Article DOI: https://doi.org/10.37284/eajfa.3.1.288

\begin{tabular}{lll}
\hline Demographic profile of respondents & & Proportion of the total (\%) \\
\hline & Married & 77.0 \\
& Divorced & 2.4 \\
& Others & 2.4 \\
Education Level & None & 6.5 \\
& Primary & 48.5 \\
& Secondary & 32.3 \\
Occupation & College & 12.9 \\
& Farmer & 75.0 \\
& Teacher & 8.1 \\
& Civil servant & 1.2 \\
Annual Income (US Dollars) & Business & 12.5 \\
& Others & 3.2 \\
& Below 50 & 2.8 \\
& $51-150$ & 56.9 \\
& $151-250$ & 19.8 \\
& $251-350$ & 16.1 \\
& Above 350 & 4.4 \\
\hline
\end{tabular}

Sixty-nine $(69 \%)$ of the study sample were male while women accounted for $31 \%$ of the total. This implied that more men were involved in forest resource conservation and management compared to women. Observation on gender composition has been attributed to the different domestic responsibilities held by women that may have reduced their chances to participate in conservation and management of community forests (Wiafe, 2014; Banana et al., 2012; Wekesa, 2017). Further, the traditional social norms of the communities living around the forest could be a contributing factor to male domination since most of these norms emphasise the superiority of men in the participation in income-generating activities.

The age distribution of the respondents is important in knowing the most effective age range active in performing forest conservation and management roles (Sanjay, 2017). Based on the results in Table 2 , the majority of respondents (37.5\%) were between the age ranges of 34 to 41 years, while the minorities $(9.3 \%)$ were between the ages of $18-25$ years. This is an indication that adults are the most active in forest conservation than youth. Adult members hold greater responsibility for fending for their families through income-generating forest conservation activities, acknowledging the significance of these activities in forest management. Moreover, youths are usually busy acquiring education in schools, some of which are further from the forest, hence limiting their

33 This work is licensed under a Creative Commons Attribution 4.0 International License. availability for participation in forest conservation activities. In terms of marital status among the CFA members, $77 \%$ were married, $18.1 \%$ were single, and $2.4 \%$ were divorced (Table 2). Examining the marital status of the CFA's was very crucial in exposing their roles in their families besides performing forest conservation and management roles. Education level greatly contributes to decision-making on matters relating to community forest conservation programs. In this study, almost half $(48.4 \%)$ of the CFA members hold primary education as their highest educational qualification, while secondary education holders accounted for (32.3\%) and college education holders (12.9\%). This means that most members had enough basic knowledge required to appreciate the significance of forestry and consequently participate in forest conservation activities through the CFA and corresponds to observations by Cheruiyot (2016). Community forestry generally assumes that the user group should have a high degree of understanding of the community forest $(\mathrm{CF})$ concept, process, their roles and responsibilities (Bastakoti and Davidsen, 2015).

Seventy-five per cent $(75 \%)$ of CFA members majorly rely on subsistence farming (including cattle rearing) and business activities for their livelihoods, while civil servants account for $1.2 \%$. CFA members can therefore participate in the forest conservation activities, which are closely related to farming to supplement their income and pegged on 
their reportedly low education attainment. As part of establishing the socio-economic attributes, the income level of the CFA members was evaluated (Table 2). A major proportion of CFA members (56.9\%) were making between 50-150 US dollars annually, while a smaller proportion (4.4\%) earns over 350 US dollars. The annual income of the vast majority of the respondents is from farming activities which is the dominant occupation in the area and businesses. Those making higher-income

annually are employed as civil servants or teachers. The reported low income by Nyangores CFA members contributes to potentially negative implications on forest exploitation and conservation. Low annual income often motivates overexploitation of forest resources while suppressing conservation efforts.

\section{Forest Conservation Activities}

Forest conservation is the practice of planning and maintaining forested areas for the benefit and sustainability of future generations (Pawar \& Rothkar, 2015). Table 3 presents the order of preference for forest conservation activities in Nyangores forest station.

\section{Table 3: Preference of Forest Conservation Activities}

\begin{tabular}{l|l}
\hline Forest activities & Response (\%) \\
\hline Seedlings propagation & 87.1 \\
Monitoring \& evaluation & 85.1 \\
Protection of regenerations & 84.7 \\
Forest management plans development & 83.1 \\
Resource mobilisation & 81.0 \\
Soil conservation and watershed management & 79.8 \\
Enrichment planting & 79.0 \\
Planning & 69.0 \\
Forest patrols & 62.9 \\
Calendar of events & 54.4 \\
Fire fighting & 23.0 \\
Silvicultural operations & 12.9 \\
Fire break construction & 8.5 \\
\hline
\end{tabular}

The major forest conservation activities in Nyangores forest station were seedlings production $(87.1 \%)$, protection of regenerates $(84.7 \%)$ and development of forest management plans $(83.1 \%)$. These findings are in agreement with studies by (Pawar \& Rothkar, 2015; Agera, 2011) who observed that the solutions to the loss of forests include allowing local communities, forest dwellers and other forest conservation practitioners to participate in the restoration of the forest for the goods and services it provides. A study carried out in Nepal found out that, several factors including deterioration in vegetation cover, qualitative and quantitative decline of water resources, degradation and pollution of soil, the encroachment of the forest and marginal lands for cultivation, grazing and settlement lead to a reduction of forest resource potential (Agera, 2011). This however could be reversed by replacing degraded sites with indigenous seedlings in order to restore the forest
(Parrotta, 2000). Firebreak construction (8.5\%) and firefighting $(23 \%)$ were the least preferred forest conservation activities and did not differ significantly from similar studies in other regions in Kenya (Kosgey, 2015; Wamae, 2013).

\section{Role of Women in Forest Conservation and Management}

Ninety-one per cent (91.9\%) of women are involved in initiating forest management plans (Table 4), despite their other domestic responsibilities. In other related studies (Agrawal and Redford, 2006; Sanjay, 2017; Kosgey, 2015) observed that women's participation in organisational decisionmaking resulted in better conditions for the conservation of forest resources in terms of the implementation of participatory forest management (PFM). Indeed, women's role in community

34 | This work is licensed under a Creative Commons Attribution 4.0 International License. 
institutions of forest governance improves conservation and regeneration (Agarwal, 2009).

Table 4: Role of Women in Forest Conservation and Management

\begin{tabular}{l|c}
\hline Role of Women in Forest Conservation and Management & $\begin{array}{l}\text { Proportion of Women Participation } \\
(\boldsymbol{\%})\end{array}$ \\
\hline Initiation of Community Forest Management Programs & 91.6 \\
Planning of CFA Program Activities & 78.7 \\
CFA Decision Making Process & 20.2 \\
Preparation of Community Forest Constitution & 77.4 \\
Involvement in Community Forest Management Activities & 72.5 \\
Participation in Community Forest Area Patrols & 64.5 \\
Drawing Calendar of Events & 56.1 \\
Participation in Enrichment Planting & 18.5 \\
Silvicultural Operations & 41.5 \\
Harvesting of Tree Products & 22.9 \\
Resource Mobilisation and Fund Raising & 75.4 \\
Distribution of Forest Resources & 52.8 \\
Monitoring and Evaluation of Forest Activities & 85.1 \\
\hline
\end{tabular}

Seventy-eight per cent $(78.7 \%)$ of the women participated in planning for community forest management activities. The planning stage is undoubtedly the most important stage of undertaking any program as it provides the basis for all management efforts associated with the program (Sanjay, 2017). Involving women in every step of the planning process is important as they feel that their knowledge and skills in the planning process are recognised.

Seventy-four per cent $(74.2 \%)$ of women were not involved in decision-making. The small percentage (25.8\%) of women who participated in decision making believed that women had a great influence in making decisions that had a positive impact on the status of the forest resource (Agrawal, 2007). Indeed, women are the main collectors of the forest resource; their roles in the formulation of forest rules could help meet their needs and, at the same time, protect the forest base.

Community forest user groups usually operate based on their constitutions. The constitution entails rules and regulations governing the conservation and management of the forest. In the case of the community forest program, the planning stage included the preparation of the group's constitution, which binds people of the group legally, while the operational plan ensures the working modalities of the group are well defined. The majority of the women $(77.4 \%)$ were involved in the preparation of the community forest user group constitution, therefore add value to the management of community forest (Table 4). It has been observed that those women who participate in drawing the forest constitution included the elite women with both indigenous and scientific knowledge from forest society (Agarwal, 2010).

The majority of women $(54.4 \%)$ were involved in the implementation of community forest management activities (Table 4). However, 46.6\% of the women who were not involved were held in performing domestic roles of bringing up the family and most of the time they were involved in household activities. Others perceived that forest implementation activities required the attention of men, hence did not bother to participate.

Forest patrols are very important when it comes to the conservation and management of a forest. They enhance the protection of the forest against degradation from either natural or animal activities. The majority of the women $(64.5 \%)$ were involved in community forest patrol (Table 4). From the focus group discussions, it was believed that women could patrol the forest area and report any illegal operations taking place without due consent from relevant authorities. They could make the arrest forest offenders and present them to the forest manager for prosecution purposes. Others believed

35 | This work is licensed under a Creative Commons Attribution 4.0 International License. 
that women were involved in nurturing regenerations through sport weeding, removal of forest litter, cleaning up the firebreaks, opening up of nature trays for easy communication in the forest, among other activities. On the other hand, the low percentage of women who were not involved in forest patrols believed that; patrols are men's activity that is more masculine than the female. During the arrest of forest offenders, women are likely to face a lot of resistance as compared to the male counterpart. This finding of this study is in line with the study by Pandolfelli et al. (2007) that found women involvement in the control of illicit grazing and illicit felling of trees in Chiang Mai, Thailand.

Fifty-six $(56.1 \%)$ of the women were actively involved in drawing up of calendar of events (construction of firebreaks, enrichment planting, nursery production and preparedness for fires season) for community forest management activities. It is believed that women entirely rely on both forest and non-forest products for their livelihood improvement, hence, their involvement in the preparation of a calendar of events as a tool of forest management for sustainable development of the country. Few women $(18.5 \%)$ participated in enrichment planting (replacement of degraded forest sites with indigenous tree species or restoration of forest composition). It is perceived that the undulating terrain of the study area restricted a large number of women on enrichment planting activity.

Forty-one $(41.5 \%)$ of the women participated in silvicultural (pruning, thinning and harvesting) operations. It is perceived that silvicultural operations are men's work; hence women have little role in such activities. Pruning involves climbing up the tree and removal of excess branches; hence women are believed to be weak and could not ascend up the tree. Women were restricted to participation in the extraction of minor forest products such as firewood, herbal medicine and fodder harvesting. These results are in agreement with the findings by the International Union for Conservation of Nature (IUCN) (2011) that describes women across the developing world as the major primary users of forest resources and their sale of non-timber forest products is vital for their household expenses. FAO (2014) describes women's control over resources may be more commonly centred on management and use of fuelwood, fodder and non-timber products. Fiftytwo $(52.4 \%)$ of women participated in resource mobilisation (sale of tree seeds, seedlings and apiculture) and fundraising activity for the conservation and management of Nyangores community forest. These findings are in line with Wamae (2013) who observed that women are more involved in generating funds from the sale of seeds, seedlings other non-forest products such as honey and herbs.

Forty-seven $(47.6 \%)$ of women are involved in the sharing of benefits accrued from sustainable forest resources management. Equitable sharing of resources will promote unity and prevent conflicts that will perhaps disintegrate the forest user group. The evaluation phase determines the relevance and achievement of objectives, developmental efficiency, effectiveness, impact and sustainability (IFRC, 2010). Eighty-five (85.1\%) of the women were involved in monitoring and evaluation (identifying variances from the project management plan and taking corrective action to meet project objectives). Generally, in the poorer parts of the world, women continue to be very dependent on forest goods and services such as firewood, fodder, soil and water protection, or regulation of the climate for their agricultural activities. It is primarily the women who work with these resources and depend on them for the well-being of their families. So, it is vital that women are put at the centre of whatever decisions are being made about how to manage these resources. These results are similar to the findings by Maurice et al. (2019) who established and emphasised the importance of women in the conservation of the Rainforest of Mount Cameroon.

\section{Socio-Economic Benefits of Forest Management and Conservation}

The study sought to understand accrued benefits to women from Nyangores community forest conservation. Ninety-six $(96.7 \%)$ of the women benefited from the extraction of herbal medicine, freshwater $(95.6 \%)$, firewood $(94.8 \%)$, knowledge $(92.3 \%)$, honey production $(88.5 \%)$, recreational values $(88.3 \%)$, fodder for animals $(78.6 \%)$, cultural value gains (58.9\%), employment $(55.6 \%)$, transmission poles $(10.9 \%)$ and timber production

36 | This work is licensed under a Creative Commons Attribution 4.0 International License. 
(8.5\%) (Table 5). These findings are in agreement with the studies done by Sanjay (2017) who found multiple benefits accrued to women's role in Panchakanya Community Forest of Nepal. Sanjay (2017) described the forest as an indispensable life support system in many developing countries around the world. FAO (2014) identifies women from rural areas as a major beneficially of forest products such as firewood, fodder. According to Sanjay (2017), approximately $83 \%$ of the population in Nepal uses fuelwood as the source of energy for their households.

Table 5: Socio-Economic Benefit of Women from Nyangores Forest

\begin{tabular}{l|ll}
\hline Benefit & $\begin{array}{l}\text { Proportion of Women } \\
(\%)\end{array}$ \\
\hline Freshwater & 95.6 & \\
Firewood & 94.8 & \\
Knowledge & 92.3 & \\
Recreational values & 88.3 & \\
Honey & 83.5 & \\
Fodder & 78.6 & \\
Cultural values & 58.9 & \\
Herbal medicine & 96.7 & \\
Employment & 55.6 & \\
Transmission poles & 10.9 \\
Timber & 8.5 & \\
\hline
\end{tabular}

Pandolfelli et al. (2007) describe women as the most active beneficiary citizen in the use of forest resources. In large part, this has to do with social and cultural expectations, which accord women primary responsibility for collecting forest products for household use. Tewari (1989) describes forests as a reservoir for social, cultural and economic importance for the survival of the Indian population.

\section{CONCLUSIONS AND RECOMMENDATIONS}

The study investigated the gender dynamics in the conservation activities of a Nyangores CFA. Results indicate tree seedling propagation $(87.1 \%)$, monitoring and evaluation (M\&E) (85.1\%) and protection of regenerates $(84.7 \%)$ as the major forest conservation activities. Minor roles included timber harvesting (22.9\%), enrichment planting, silvicultural operations (12.9\%) and firefighting (8.5\%). Accrued socio-economic benefits as a result of women's role in forest management and conservation were freshwater (95.6\%) and firewood (94.8\%). These results suggest the incorporation of both human genders as a pre-requisite for the success of community forest conservation programs in Mau Conservancy Kenya.

\section{ACKNOWLEDGEMENTS}

The authors are grateful to the members of Nyangores CFA who participated in this study, Ecosystem Conservator, Conservancy (Mr. Mwai Muraguri), the entire staff at Narok Forest Station, Mau Head of Conservancy (Mr. Fred Ogombe) and the entire KFS staff fraternity for their valuable contribution in this research.

\section{REFERENCES}

Agarwal, B. (2001). Participatory exclusions, community forestry and gender: An analysis for South Asia and a conceptual framework. World Development, 29 (10), 1623-1648.

Agarwal, B. (2007). Gender inequality, cooperation, and environmental sustainability. In Baland, J. M., Bardhan, P. K. \& Bowles, S. (Eds), Inequality, cooperation, and environmental sustainability (pp. 274-313). New York, NY: Russell Sage Foundation and Princeton University Press.

Agarwal, B. (2009). Gender and forest conservation: The impact of women's participation in community forest governance. Ecological Economics 68 (11), 2785-2799.

Agarwal, B. (2010). The impact of women in Nepal's community forestry management. The impact of women in Nepal's community forestry management., (57), 26-29.

Agera, S. I. N. (2011). Role of beekeeping in the conservation of forests. Global Journal of Agricultural Sciences, 10(1), 27-32.

Agrawal, A. \& Redford, K. (2006). Poverty, development, and biodiversity conservation: Shooting in the dark? Working Paper NO. 26. Wildlife Conservation Society.

37 This work is licensed under a Creative Commons Attribution 4.0 International License. 
Agrawal, A., Cashore, B., Hardin, R., Shepherd, G., Benson, C., \& Miller, D. (2013). Economic contributions of forests. United Nations Forum for Forestry Tenth Session. Istanbul, Turkey.

Banana, A. Y., Bukenya, M., Arinaitwe, E., Birabwa, B., \& Ssekindi, S. (2012). Gender, tenure and community forests in Uganda. Center for International Forestry Research.

Bastakoti, R. R., \& Davidsen, C. (2015). Nepal's REDD+ readiness preparation and multistakeholder consultation challenges. Journal of Forest and Livelihood, 13(1), 30-43.

Chao, S. (2012). Forest Peoples: Numbers across the world. Moreton-in-Marsh, UK: Forest Peoples Programme

Cheruiyot, K. J. (2016). Analysis of household water demand, distribution and community management strategies in Nyangores Subcatchment, Bomet County, Kenya. Master's Thesis, Kenyatta University.

Coleman, E. A., \& Mwangi, E. (2013). Women's participation in forest management: A crosscountry analysis. Global Environmental Change, 23(1), 193-205.

FAO. (2011). Forests for improved nutrition and food security. Rome, Italy: FAO.

FAO. (2014). Women in forestry: Challenges and opportunities. Rome, Italy: FAO.

FAO. (2016). State of the world's forests 2016. Forests and agriculture: Land-use challenges and opportunities. Rome: FAO.

Geller, S., McConnell, R., \& Wanyiri, J. (2006). Linking national forest programmes and poverty reduction strategies. UNASYLVA-FAO-, 57(3), 56.

International Federation of Red Cross and Red Crescent Societies (IFRC). (2010). Project/ programme planning: Guidance manual. Geneva, Switzerland: IFRC.

IUCN. (2011). Attending to Gender. The IUCN Forest Conservation Newsletter, Issue 43.
Kosgey, B. A. (2015). An assessment of the implementation of Participatory Forest Management (PFM) by Ngong Road Community Forest Association (CFA) In Nairobi County, Kenya. Unpublished Thesis, University of Nairobi.

Leone, M. (2013). Women as decision makers in community forest management: Evidence from Nepal. Journal of Development Economics, 138, 180-191.

Maurice, M. E., Fuashi, N. A., Zeh, A. F., Ebong, E. L., Flaubert, O. A., Konjieh, H., \&Daizy, N. F. (2019). An Exploration on the Perception of the Inhabitants of Muyuka Municipality Towards the Conservation of Francolins, Southwest Region, Cameroon. International Journal of Life Sciences, 8(1), 19-27.

Mugenda, O., \& Mugenda, A. (2003). Research Methods: quantitative \& qualitative approaches. Nairobi, KE: Acts Press.

Musyoki, J. K., Mugwe, J., Mutundu, K., \& Muchiri, M. (2013). Determinants of household decision to join community forest associations: a case study of Kenya. International Scholarly Research Notices, 2013, 1-11.

Mutune, J. M., Wahome, R. G., \&Mungai, D. N. (2015). Local Participation in Community Forest Associations: A Case Study of Sururu and Eburu Forests, Kenya. International Journal of African and Asian Studies, 13, 84-94.

Pandolfelli, L., Dohrn, S., \&Meinzen-Dick, R. S. (2007). Gender and collective action: policy implications from recent research. Policy Brief Number 5. Washington, DC: CAPRI.

Parrotta, J. A. (2000). Catalysing natural forest restoration on degraded tropical landscapes. Forest Restoration for Wildlife Conservation. International Tropical Timber Organization and the Forest restoration Research Unit, Chiang Mai University, Thailand

Pawar, K. V., \& Rothkar, R. V. (2015). Forest conservation \& environmental awareness. Procedia Earth and Planetary Science, 11, 212-215.

38 This work is licensed under a Creative Commons Attribution 4.0 International License. 
Sanjay, S. (2017). Women's Roles in Community Forestry Program: A Case of Panchakanya Community Forest User Group of Nuwakot District, Nepal. Master's Thesis, Ritsumeikan Asia Pacific University.

Sen, A. (2000). Social exclusion: concept, application and scrutiny. Social Development Papers No. 1. Office of Environment and Social Development Asian Development Bank

Shackleton, C., Shackleton, S., \& Shanley, P. (2011). Building a holistic picture: An integrative analysis of current and future prospects for non-timber forest products in a changing world. In Non-timber forest products in the global context (pp. 255-280). Springer, Berlin, Heidelberg.

Springate-Baginski, O., \& Blaikie, P. (2003). Is community forestry in contemporary Nepal propoor and sustainable. A Policy Process Analysis. Stockholm Environment Institute, York.

Tewari, P. D. (1989). Nutritional Problems in Rural India: A Case study of Sagar-Damoh Plateau. Northern Book Centre.

Usman, Y., Danjuma, M. N., \& Abdulkarim, I. A. (2016). Roles of forest resources in sustaining rural livelihoods around Yankari Game Reserve, Nigeria. Pyrex Journal of Geography and Regional Planning, 2(1), 11-15.

Wamae, T. M. (2013). Impact of community forest associations on forest resources management in Kenya. Master's Thesis, University of Nairobi.

Weiss, G., Gudurić, I. \& Wolfslehner, B. (2012). Review of forest owners' organisations in selected Eastern European countries. Forestry Policy and Institutions Working Paper NO. 30. Rome. Italy: FAO

Wekesa, I. W. (2017). Examining the role of community participation in forest management and conservation in Kimothon forest, Trans Nzoia County, Kenya. Master's Thesis, University of Nairobi.
Wiafe, E. D. (2014). Tree regeneration after logging in rain-forest ecosystem. Research Journal of Biology, 2, 18-28.

Williams, P. J. (1992). Women, trees and forests in Africa - A resource guide. Nairobi, KE: Environnent Liaison Centre International (ELCI)

Yemshaw, Y. (2007). Collaborative Forest management in Africa. In limbo? In: Participatory Forest Management (PFM), Biodiversity, and Livelihoods in Africa. Proceedings of an international conference. 1921 March 2007. Addis Ababa, Ethiopia: 190201. 